\title{
The Impact of Waste Management on Tourism Sustainability in Labuan Bajo, West Manggarai Regency in 2019
}

\author{
Ernesta Leha \\ Department of Management \\ Faculty of Economic Development \\ Ende, Indonesia \\ leha_ernesta@yahoo.com \\ Daniel Wolo \\ Department of Physics Education \\ Faculty of Teacher Training and Education \\ Ende, Indonesia \\ dewolochem@gmail.com
}

\author{
AprianaMarselina \\ Accounting Department \\ Faculty of Economic \\ Ende, Indonesia \\ aprilradja82@gmail.com
}

\author{
Helena Rosalina Parera \\ Department Economic Education \\ Faculty of Teacher Training and Education \\ Ende, Indonesia \\ pareralena@gmail.com
}

\begin{abstract}
As the leading tourism destination for premium class, Labuan Bajo, West Manggarai, East Nusa Tenggara (NTT) continues to improve. Starting from the infrastructure development that continues to accelerate to the issue of waste management. The main focus of the waste problem in Labuan Bajo, namely, beaches and road reclamation. Garbage is still being dumped carelessly by residents and business actors domiciled in the vicinity of tourist sites. This study the perceptions of the Impact of Waste Management on Tourism Sustainability in Labuan Bajo have been studied in terms of ecological aspects. The data used in this study are primary data and secondary data. Primary data were collected through direct interviews with selected respondents and experts, as well as observations at the research location. Methods of data collection are carried out through interviews, discussions, questionnaires, and field surveys. Meanwhile, secondary data was collected from various sources including, data from the District and Provincial BPS, the Tourism Office, Bappeda, DLH Deperindag and, the Cooperative Office in West Manggarai Regency. The results of data analysis using ordination and leverage analysis prove that tourism development in this area still requires more intensive intervention in the ecological dimension. The sustainability status of tourism in terms of environmental management in Labuan Bajo is in reasonably sustainable condition.
\end{abstract}

Keywords-Labuan Bajo, Waste Managemen, Ordination Analysis, Laverage Analysis

\section{INTRODUCTION}

The development of tourism activities in Labuan Bajo has increased considerably from year to year. This increase can be seen from the number of tourists who enter each year to enjoy this city's natural beauty. The increasing flow of tourists is also in line with the efforts of the Regional Government and the Central Government to fix and build tourism infrastructure in Labuan Bajo. Several approaches are taken by the government, such as regulating hotel and restaurant taxes, have not been able to have a significant impact on waste management. This is in line with previous research that examined the correlation between hotel and restaurant tax increases and the waste problems caused by hotels and restaurants. [3]

\section{Review Literature}

As a growing new leading destination, the city of Labuan Bajo is also inseparable from the same problems as other tourism cities, such as social, economic, and environmental problems, which are the impact of tourism development. The complaints commonly raised by tourists are about cleanliness, the availability of tourism accommodation, and hospitality.[4].

At some level, tourists' complaints are common. Even in Bali, where the population can be said to be accustomed to the world of tourism, there are still tourists' complaints about many things [10]. However, for now, tourists' complaints regarding garbage (especially plastic waste) in Labuan Bajo cannot be said to be ordinary anymore. In plain view, there is still a lot of garbage scattered in many destinations, in city corners, even in front of people's houses. And the waste problem in Labuan Bajo has become a national issue that has been widely echoed through the media.

Tourists who visit each tourist destination generally enjoy the natural beauty and cultural uniqueness of a region and expect comfort in terms of service and cleanliness [11]. Cleanliness of a destination, especially concerning environmental sustainability, is one of the priority things tourists need[5]. The initial survey conducted in Labuan Bajo City in April 2019 shows that there are still many things that need to be addressed, especially those related to sustainability in many aspects, and waste is one of them. Garbage is still being disposed of carelessly by residents and business actors domiciled in tourist sites' vicinity. Still, the rapid development of tourism infrastructure has also created a new volume of waste, such as in markets and shopping centers[8].

Garbage is a complex problem because it is related to the availability of supporting facilities and infrastructure and 
human resources [12]. A destination will be free from waste, depending on how much effort the people in this area make to protect the environment. Willingness to protect the environment is closely related to the customs and culture that shape people's character[6]. Labuan Bajo is a city that is a bit complex and unique because the population in this area is a heterogeneous community, which is a mix of residents and residents from outside the West Manggarai area. This condition causes efforts to solve the waste problem and must also be started from in-depth studies to obtain the right solution.

Perception Study of the Impact of Waste Management on Tourism Sustainability in Labuan Bajo in terms of ecological aspects. The objectives are (1) Knowing the sustainable status of tourism development in Labuan Bajo from an ecological (environmental) aspect, (2) Knowing how much impact of waste management has been carried out by the Regional Government so far, (3) Knowing the perceptions of the community, stakeholders and managers about waste management in the City of Labuan Bajo and (4) Providing recommendations for effective and efficient waste management for the West Manggarai Regional Government.

\section{METHOD}

This research was conducted in Labuan Bajo, which is the capital city of West Manggarai. Labuan Bajo is divided into 15 development areas, namely Kampung Ujung, Kampung Tengah, Kampung Air, Lamtoro, Wae Kelambu, Wae Medhu, Coang Ndereng, Wae Kesambi, Wae Bo, Lancang, Sernaru, Wae Metar, Pasar Baru, Pede, and Gorontalo. In addition, the study will also collect secondary data from BPS and related agencies. The research was conducted from August to September 2019, starting from the preparation of the proposal to the preparation of the research results.

The data used in this study are primary data and secondary data. Primary data were collected through direct interviews with selected respondents and experts, as well as observations at the research location. Methods of data collection are carried out through interviews, discussions, questionnaires, and field surveys. Meanwhile, secondary data was collected from various sources, including data from the District and Provincial BPS, the Tourism Office, Bappeda, DLH Deperindag, and the Cooperative Office in West Manggarai Regency.

\section{Data analysis}

Data collection uses several methods, namely: (1) Questionnaire method, namely data collection by distributing questionnaires to tourism business actors and the Labuan Bajo community as well as stakeholders who know the potential for sustainable tourism development in Labuan Bajo; (2) In-depth interview, namely data collection by conducting in-depth interviews with key informants, namely competent parties who can provide descriptions and information used to answer the problems in this study; (3) Observation, namely data collection by making direct observations to the research location to get a clear picture of the tourism being researched and to find out firsthand about the internal and external environment of sustainable tourism in Labuan Bajo; (4) Document analysis, which is carried out incompetent institutions such as the Tourism Office, Environmental and Cleanliness Service (DLHK), BPS, Licensing Service and Komodo National Park to collect secondary data and data from previous studies and (5) Focus Group Discussion (FGD) ) is an interview-based discussion to generate qualitative data and explore specific problems. This technique is intended to obtain data from a group based on the discussion results on a particular issue. The number of respondents is determined based on the Slovin formula, and the selected respondents consist of 4 categories, namely from the community, business actors, managers, and stakeholders or experts.

Respondents from the community

Respondents from the community were determined using the Slovin and Uma Sekaran equation formulas as follows:

$$
n=\frac{N}{1+\left(N(M o e)^{2}\right)}
$$

where: $\mathrm{n}=$ number of samples; $\mathrm{N}=$ total population; Moe $=$ Margin of Error Maximum (tolerable error, set at 10\%). The data analysis method used in this study is Multi Dimensional Scaling (MDS) with two stages of analysis, namely Rap Analysis and Leverage analysis and qualitative descriptive analysis to determine the impact of waste management.

\section{DATA, DISCUSSION, AND RESULTS/FINDINGS} Waste Management Situational Analysis in Labuan Bajo Based on data from the Environment and Sanitation Office of West Manggarai Regency, it is known that waste management in Labuan Bajo City still uses a collect-transport disposal system. (Figure 1 ).

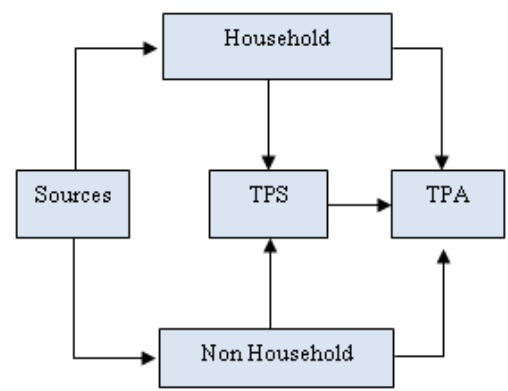

Figure 1. Flow of Waste Management for the City of Labuan Bajo

The current coverage of waste services in West Manggarai Regency in urban areas is $38.5 \%$ and transported to the TPA. The remaining $44.5 \% \mathrm{~d}$ is managed independently by the community or has not been served, and $17 \%$ has not been processed. By services in rural areas, nothing has been transported to the TPA, where $72.3 \%$ are thought to be managed independently by the community or have not even been served, and the remaining $28 \%$ of waste is not processed. [1].

The sources of waste observed came from the urban areas of Labuan Bajo, Komodo Village, Pasir Panjang Village (Rinca Island), Papa Garang Village (Papa Garang Island), and Padar Island. The average size of household waste generation is 2.49 liters / person / day or equivalent to $0.29 \mathrm{~kg} /$ person / day. This average generation is following the standard of generation in Small Towns.

Based on the source, most waste generation came from housing (7.3 tonnes/day) followed by roads with 2.3 tonnes, restaurants by 1.7 tonnes, and markets as much as 1.6 tonnes/day. In terms of volume, the largest waste generation comes from housing as much as $63.5 \mathrm{~m} 3$, offices $14.4 \mathrm{~m} 3$ and restaurants $10.3 \mathrm{~m} 3$, roads as much as $9.3 \mathrm{~m} 3$, and markets 7.2 $\mathrm{m}^{3}[1]$.

Garbage in Labuan Bajo City is dominated by organic waste in food scraps, which reaches $33.64 \%$ of the total waste generation. Waste with the second-largest composition from the household sector is salable paper waste amounting to $16.97 \%$. Meanwhile, types of waste, including B3 (electronic 
and medical), accounted for $2.53 \%$. The composition of nonhousehold waste is also dominated by food waste at $36.28 \%$, but the amount is less than non-organic waste. The secondhighest amount of salable paper is $20 \%$. Meanwhile, waste which is classified as B3 (Glass, Electronic, and Medical) is $0.88 \%[1]$.

Based on information from the Sanitation and Environment Agency, waste collection services in the Labuan Bajo Urban area have reached the following service percentages:

a) Labuan Bajo Urban Village reaches $100 \%$ service

b) Kelurahan Wae Kelambu only reaches $30-40 \%$

c) Gorontalo Village reaches $100 \%$ service

d) Batu Cermin Village reaches $60-70 \%$ service

The collection pattern carried out in Labuan Bajo City is directly individual, namely door-to-door using a garbage truck, garbage motorbike, or pick-up car. In this system, the process of collecting and transporting waste is carried out simultaneously. The garbage from each source will be collected, whether in the communal containers located along the main road or in the backyard of the hotel/office area, collected and transported directly to the TPA.

Currently, the garbage collection pattern in settlements is generally carried out by direct transportation using a garbage truck to be sent directly to the Final Processing Site (TPA) [2] . However, some of them have been collected independently from the waste bank or TPS 3R. The technique of collecting and transporting waste in Labuan Bajo City is as follows:

a) Transportation is carried out every day

b) There are three shifts in a day, namely the morning schedule around 07: 00 WITA, schedule

c) noon around 11:00 WITA and afternoon schedule around 16:00 WITA.

d) This schedule is tentative and subject to change, depending on the garbage collectors and collectors' conditions.

e) The number of garbage collectors assigned to collect and transport garbage is around 4-5 officers.

f) Technical activities for collecting and transporting waste are carried out in Labuan Bajo Village.

g) Time for the technical activities of collecting and transporting waste is around 5 - 6 hours.

h) The garbage collection unit provided is in the form of a garbage motorbike dump truck (tricycle) and an open pickup truck

The obstacles that are still found regarding the transportation of waste in Labuan Bajo are as follows:

a) The number of TPS is still small, so for motorbikes and pick-up cars, they have to travel quite a long distance to get to the TPA

b) If there are enough TPS, then the motorbike unit and the pick-up unit can take them to the TPS. Furthermore, this will be carried out by trucks that will dump at the TPA

c) Garbage at the source location often piles up and is not transported by DLHK

d) The condition of the TPA is already full capacity, causing protests from residents around the TPA, whose land is often buried with garbage from open dumping activities at the TPA

From the aspect of final processing, some of the problems encountered are:

a) Waste Final Processing (TPA) is not well managed.

b) The existing TPA is still in the form of open dumping, and a lot of garbage is scattered from the entrance to the TPA c) A landfill called TPA Kaper is located in Golo Bilas Village, Komodo District, with a distance of $\pm 5 \mathrm{~km}$ from the city center with a landfill area of $3,500 \mathrm{~m}^{2}$ since 2005 .

d) The land used in TPA Kaper is government-owned, but because of its high location, a lot of garbage is carried by flooding towards Pede beach, which causes Pede Beach to become dirty

e) Garbage that enters the landfill is not sorted and is only burned to reduce its volume.

f) There is very little scavenger activity at the TPA location and also in urban areas. Besides that, there are not many collectors of recycled waste because recycling waste management is still dominant in Java, so it is not economical, especially in terms ofthe newest TPA transportation called TPA Warloka has not been used because it is quite far from the city center

Sustainability Analysis (Ordination Analysis and Leverage Analysis)

One of the essential steps to take in a sustainability study is to capture the sustainability of the area under study. The assessment of the impact of waste management and public awareness conducted in Labuan Bajo discussed more (1) how the waste management mechanism in this area and its obstacles and (2) how the community understands waste and its management so far. However, for this study to be more complete, an analysis of the sustainability status of Labuan Bajo City was conducted in terms of 5 aspects, namely ecology, economy, socio-culture, technology, and infrastructure, as well as legal and institutional factors.

Besides, a leverage analysis was carried out to capture the dominant attributes or variables affecting sustainability in Labuan Bajo. The characteristics or variables used to describe the sustainability status in this study are still very limited and may not represent. As a preliminary study, the results can be used as an illustration of the current Labuan Bajo situation.

\section{Ecological Aspects}

The results of the analysis of the ordination of the ecological aspects are on a scale of 53.00, which means that the sustainability status of Labuan Bajo tourism development from an environmental factor is at a reasonably sustainable level.

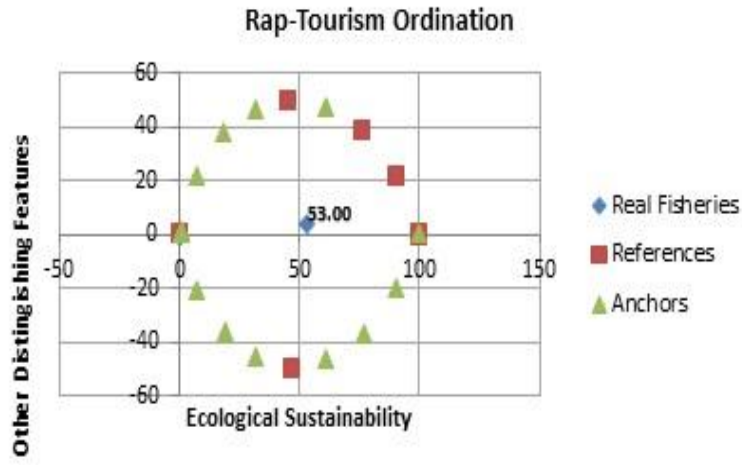

Figure 2. Results of the Ordination of Ecological Aspects of Tourism in Labuan Bajo

The results of the ecological aspect leverage analysis show that the dominant attributes have an effect on the sustainability of tourism in Labuan Bajo: (1) the carrying capacity of the tourism area $(2,34),(2)$ the number of waste piles (1.85) and (3) the pollution index (water, air, and land) (1.75). The other attributes are quite influential but on a smaller scale. This means that these three attributes are 
variables that require immediate intervention so that the sustainability of the ecological aspects can increase from a lower level to a better grade.

\section{Leverage of Attributes}

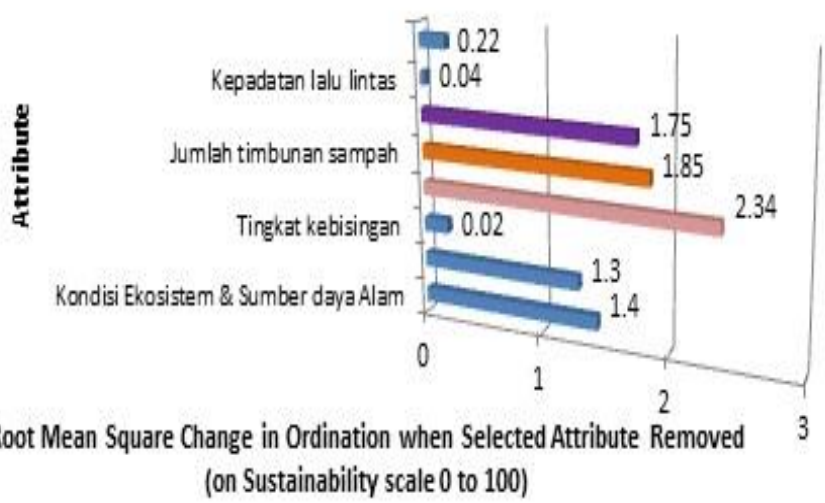

Figure 3. Results of Leverage Analysis of Ecological Aspects of Tourism in Labuan Bajo

\section{Economic Aspects}

The results of the analysis of the ordination of economic aspects are at a scale of 68.2, which means that the sustainability status of Labuan Bajo tourism development from a financial part is at a sustainable level.

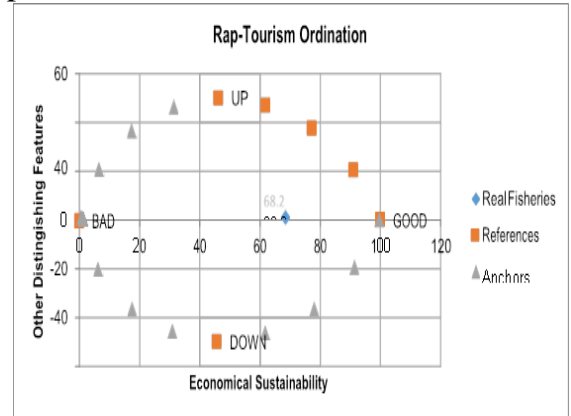

Figure 4. Results of the Ordination Analysis of the Economic Aspects of Tourism in Labuan Bajo

The results of the economic aspect leverage analysis show that the variables or attributes that are dominant in influencing the sustainability of tourism in Labuan Bajo are (1) Competitiveness against other areas (4.51), (2) Number of tourist visits (4.38), (3) and Additional job opportunities (3.08). Other influential attributes are tourism contribution to per capita income, price stability, and the low contribution of revenue from the tourism sector.

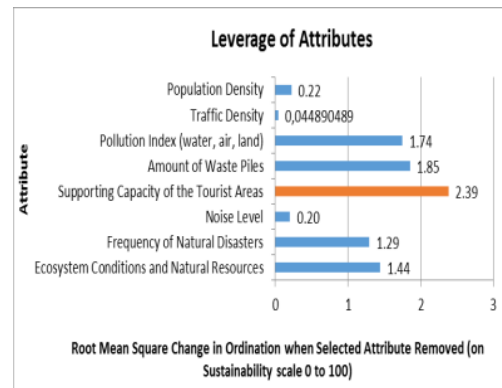

Figure 5. Results of Leverage Analysis of Economic Aspects of Tourism in Labuan Bajo

\section{Social and Cultural Aspects}

The results of the ordination analysis of social and cultural aspects are on a scale of 53.23, which means that the sustainability status of Labuan Bajo tourism development from social and cultural elements is at a reasonably sustainable level.

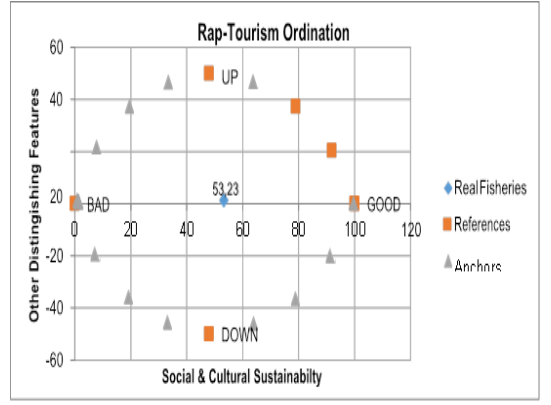

Figure 6. Results of the Ordination Analysis of the Socio-

Cultural Aspects of Labuan Bajo Tourism

The results of the socio-cultural aspect analysis show that the variable or attribute that most dominantly affects the sustainability of tourism in Labuan Bajo is the traditional handicraft market (2.27)

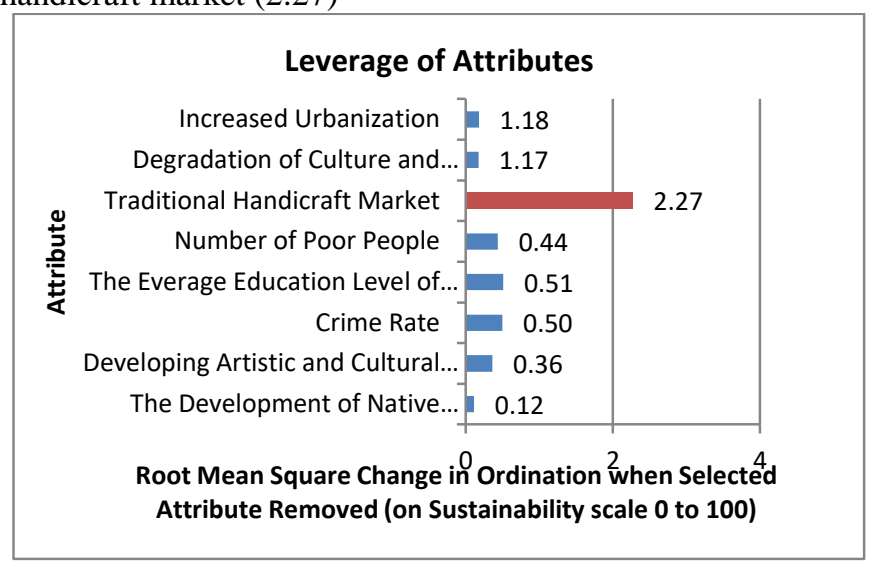

Figure 7. Results of Leverage Analysis of the Socio-Cultural Aspects of Labuan Bajo Tourism

\section{Technology and Infrastructure Aspects}

The results of the analysis of the ordination of technology and infrastructure aspects are at a scale of 53.13, which means that the sustainability status of Labuan Bajo tourism development from the technological and infrastructure aspects is at a reasonably sustainable level.

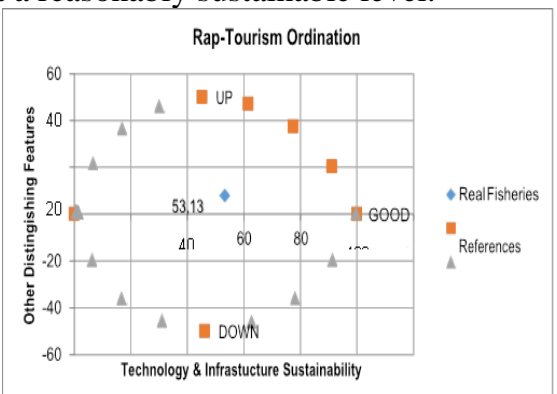

Figure 8. Results of the Ordination Analysis of the Labuan Bajo Technology and Infrastructure Aspects

The results of the analysis of technology and infrastructure aspects show that the variables or attributes that most dominantly influence the sustainability of tourism in Labuan Bajo are (1) the number of tourism accommodation (hotels, homestays, restaurants, etc.) (3.71); (2) net (3.0 (((3.07) (3) public transport figures (2.98) and (4) Technology adoption rate (e-tourism online transportation system, online ordering, etc.) (0.54) 


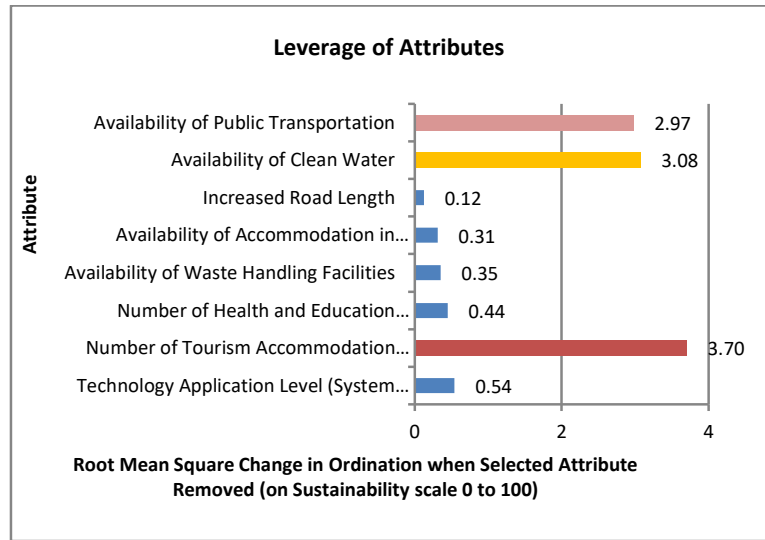

Figure 9. Results of Leverage Analysis on Technology \& Infrastructure Aspects of Labuan Bajo

Legal and Institutional Aspects

results of the analysis of the ordination of legal and institutional aspects are on a scale of 47.02, which means that the sustainability status of Labuan Bajo tourism development from legal and institutional elements is at a less sustainable level.

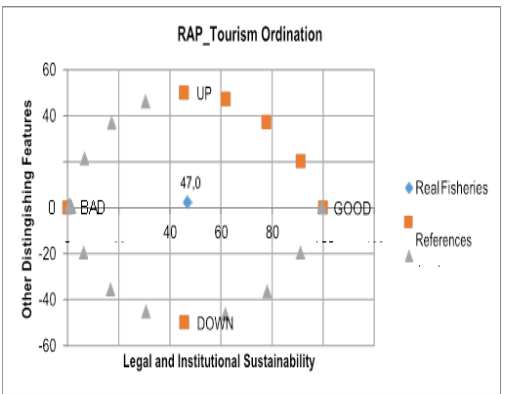

Figure 10. Result of Leverage Analysis of Legal \& Institutional Aspects in Labuan Bajo

The results of the leverage analysis on legal and institutional aspects show the variables or attributes that most dominantly affect the sustainability of tourism in Labuan Bajo are (1) the number of buildings and businesses that do not have a license that is regulated (1.61), (2) The availability of integrated tourism institutions (1),59) and (3) the frequency of policy socialization (1.47).

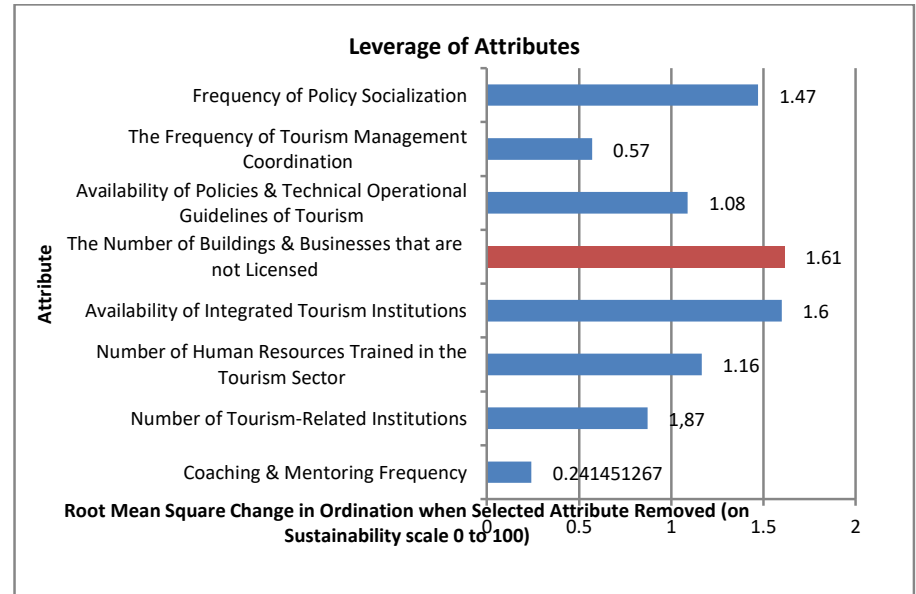

Figure 11. Result of Leverage Analysis of Legal and Institutional Aspects in Labuan Bajo

Summary of the Status of Tourism Sustainability in Labuan Bajo

The sustainability status of an area or destination can be assessed from each dimension. Still, it can also be studied in a multi-dimensional manner, meaning that all variables used in each of these dimensions are combined and analyzed by specific methods, in this case, using the ordinated analysis method. The results of the multi-dimensional analysis for Labuan Bajo show that the sustainability of tourism development in Labuan Bajo is at a reasonably sustainable status with a scale of 56.78. This shows that tourism development in this region still requires more intense intervention in all dimensions, including ecology, economy, socio-culture, technology, infrastructure, and law and institutions (Figure 12).

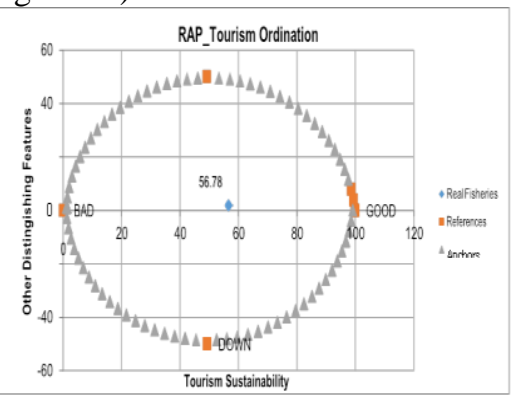

Figure 12. Status of Sustainable Tourism Development in Labuan Bajo Overview

Tourism sustainability in each dimension or aspect in Labuan Bajo can be seen in the 'kite diagram' (Figure 11). Based on the kite diagram image, it can be seen that the condition of sustainable tourism in Labuan Bajo is still far from ideal conditions (scale 100).

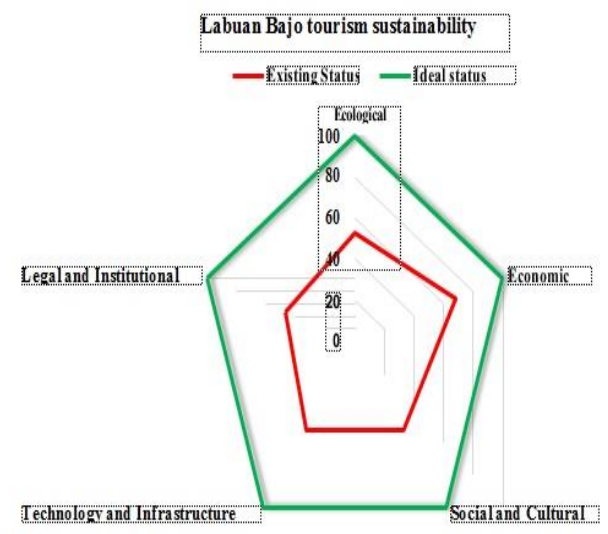

Figure 13. Kite Diagram of Tourism Sustainability in Labuan Bajo

\section{CONCLUSIONS AND SUGGESTIONS} Conclusion and Recommendation Study

\section{Conclusion}

1) Based on the results of a study on the sustainability status of tourism development in Labuan Bajo, it is known that:

- The ecological aspect is in a moderately sustainable status

- The economic element is in a reasonably sustainable status

- Social and cultural elements are in a sufficiently sustainable status

- The technology and infrastructure aspects are in a reasonably sustainable status

- Legal and institutional factors are in a less sustainable status

2) While the status of the sustainability of tourism development is reviewed in general or multidimensional, it is in the reasonably sustainable category

3) Based on the results of the study on the impact of waste management and public awareness, the following results were obtained: 
- In this case, DLHK still experiences limitations in terms of facilities and infrastructure for waste management, namely trash bins and TPS.

- The Department of Environment and Sanitation is still experiencing problems related to the number of workers who handle waste, especially waste in the city, which affects the inefficient waste transportation mechanism.

- Knowledge, understanding, and public awareness of the importance of managing waste is still deficient

- The majority of the community stated that the local government did not involve the community in handling waste in Labuan Bajo

- The community also noted that the local government was not maximal in conducting counseling and training as well as campaigns related to waste management in Labuan Bajo

- The society stated that the Regional Government's exemplary elements regarding discipline in terms of cleanliness were also deficient. One example, when the Regional Government conducts official ceremonies, it always leaves plastic waste scattered along with the venue

- The community also stated that they are willing to be trained and involved in waste management efforts in Labuan Bajo

\section{Recommendations from the Results of the Labuan Bajo Tourism Sustainability Analysis}

For the status of tourism sustainability to be improved, the Regional Government and stakeholders need to intervene in the dominant variables affecting sustainability based on the following aspects:

Ecological Aspects: (1) carrying capacity of tourist areas, (2) Amount of waste piles and (3) Pollution index (water, air, and soil), in this context water pollution, although it cannot be ascertained that it is due to tourism activities

Economic Aspects: (1) Competitiveness against other regions (2) Number of tourist visits (3) Increasing employment opportunities, (4) Contribution of tourism to per capita income, (5) price stability and (6) contribution of revenue from the tourism sector against PAD

Social and Cultural Aspects: Traditional Craft Market

Technology and Infrastructure Aspects: (1) Number of tourism accommodation facilities (hotels, homestays, restaurants, etc.), (2) Availability of clean water, (3) availability of public transportation, and (4) Level of technology application (etourism transport system online, online booking, etc.)

Legal and Institutional Aspects: (1) Number of buildings and businesses that do not have a license that is regulated, (2) Availability of integrated tourism institutions, and (3) Frequency of policy socialization

\section{REFERENCES}

[1] Dinas Lingkungan Hidup dan Kebersihan Manggarai Barat, 2017, Data Hasil Kajian Pengelolaan Sampah di Labuan Bajo. Labuan Bajo : DLHK

[2] Badan Standardisasi Nasional. (2008). SNI 3242:2008 tentang Pengelolaan sampah di permukiman. Badan Standardisasi Nasional, 123.

[3] Chaabane, W., Nassour, A., \& Nelles, M. (2018). Solid waste management key indicator development for hotels: A tunisian case study analysis. Recycling, 3(4). https://doi.org/10.3390/recycling3040056

[4] Gusti Ngurah Bagus Kusuma Putra, G. A. M. S. (2018). Fenomena Media Periklanan Terhadap Citra Kota Denpasar Studi Kasus di Beberapa Persimpangan Kota Denpasar. Ruang SPACE, 5(2).

[5] I Putu Juniartha, Made Antara, M. S. (2019). Pengelolaan Sampah Berbasis Masyarakat Di Desa Pakraman Padangtegal Kecamatan Ubud Kabupaten Gianyar. ECOTROPHIC : Jurnal Ilmu Lingkungan (Journal of Environmental Science), 13(2), 205-214.
[6] Ika Yuli Andarwati, NurHilal, \& TeguhWidiyanto. (2018). Studi Pengelolaan Bank Sampah Pada Kantor Dinas Pemerintah Daerah Kabupaten Banyumas Tahun 2017. Keslingmas, 37(660), 1-59. Retrieved from www.depkes.go.id/...profil/PROFIL_KAB_KOTA_2013/3302_Jateng_ Kab_Banyum..

[7] Indriyanti, D., Banowati, E., \& Margunani, M. (2015). Pengolahan Limbah Organik Sampah Pasar Menjadi Kompos. Jurnal Abdimas, 19(1).

[8] Rachman, M. F., Kusumaningrum, R., \& Khomsatun, K. (2018). Studi Pengelolaan Sampah Di Pasar Sayur Dan Buah Kecamatan Pemalang Kabupaten Pemalang Tahun 2016. Buletin Keslingmas, 37(1), 70. https://doi.org/10.31983/keslingmas.v37i1.3827

[9] Sudiro, S., Setyawan, A., \& Nulhakim, L. (2018). Model Pengelolaan Sampah Permukiman Di Kelurahan Tunjung Sekar Kota Malang. Plano Madani: Jurnal Perencanaan Wilayah Dan Kota, 7(1), 106-117. https://doi.org/10.24252/planomadani.v7i1a10

[10] Sutawa, G. K. (2012). Issues on Bali Tourism Development and Community Empowerment to Support Sustainable Tourism Development. Procedia Economics and Finance, 4(Icsmed), 413-422. https://doi.org/10.1016/s2212-5671(12)00356-5

[11] Trimurti, C. P., \& Utama, I. G. B. R. (2019). an Investigation of Tourism Motivation and Tourist Attraction of Tourists To Bali. Jurnal Manajemen Dan Kewirausahaan, 21(2), 130-133. https://doi.org/10.9744/jmk.21.2.130-133

[12] Wulansari, D., Ekayani, M., \& Karlinasari, L. (2019). Kajian Timbulan Sampah Makanan Warung Makan. ECOTROPHIC: Jurnal Ilmu Lingkungan (Journal of Environmental Science), 13(2), 125. https://doi.org/10.24843/ejes.2019.v13.i02.p01 